\title{
Effect of storage temperature on prokaryotic cell counts and community composition analysis from fixed and filtered seawater samples
}

\author{
Christine Beardsley $\cdot$ Shaun M. Moss · \\ Farooq Azam
}

Received: 23 April 2007 /Revised: 26 July 2007/Accepted: 7 August 2007/Published online: 11 September 2007

(C) Springer-Verlag and AWI 2007

\begin{abstract}
Marine, pelagic prokaryotes commonly are visualized and enumerated by epifluorescence microscopy after staining with fluorescent, DNA-binding dyes and sample preparation and storage has a major influence on obtaining reliable estimates. However, sampling often takes place in remote locations and the recommended continuous sample storage at $-20^{\circ} \mathrm{C}$ until further sample evaluation is often logistically challenging or infeasible. We investigated the effect of storage temperature on fixed and filtered seawater samples for subsequent enumeration of total prokaryotic cells and community composition analysis by fluorescence in situ hybridization (FISH). Prokaryotic abundance in surface seawater was not significantly different after 99 days when filters were stored either at room temperature (RT) or at $-20^{\circ} \mathrm{C}$. Furthermore, there was no loss in detection rates of phylotypes by FISH from filters stored at RT or $-20^{\circ} \mathrm{C}$ for $28-30$ days. We conclude that fixed and filtered seawater samples intended for total prokaryote counts or for FISH may be maintained
\end{abstract}

Communicated by C. Schütt.

C. Beardsley · F. Azam

Scripps Institution of Oceanography,

University of California, San Diego,

9500 Gilman Dr., La Jolla, CA 92093-0202, USA

Present Address:

C. Beardsley $(\square)$

Institut für Chemie und Biologie des Meeres,

Carl von Ossietzky Universität Oldenburg,

C.-v.-Ossietzky-Str. 9-11, 26129 Oldenburg, Germany

e-mail: c.beardsley@icbm.de

S. M. Moss

Oceanic Institute, 202 Kalanianaole Hwy,

Waimanalo, HI 96795, USA long-term at room temperature, and this should logistically facilitate diverse studies of prokaryote ecology, biogeography, and the occurrence of human and fish/shellfish pathogens.

Keywords Marine bacteria - Storage temperature . Prokaryotic abundance $\cdot$ Microbial community composition · Fluorescence in situ hybridization

\section{Introduction}

Direct enumeration of prokaryotes from seawater samples using DNA-binding stains and epifluorescence microscopy (Zimmermann and Meyer-Reil 1974; Daley and Hobbie 1975) revolutionized the field of marine microbial ecology. Because of these advances, it was recognized that the world's oceans harbor microbes at much higher abundances than had been estimated from culture-based methods. Staining protocols and detection methods have been modified since their first introduction (Jones and Simon 1975; Hobbie et al. 1977; Porter and Feig 1980; Monger and Landry 1993) and DAPI counts, by microscopy or flow cytometry, are now accepted as reliable estimates of in situ abundances. In combination with microbial production measurements, abundance estimates have been indispensable for our understanding of carbon and nutrient fluxes in the ocean. Furthermore, the discovery of the importance of marine bacteria and archaea has driven methodological advances, especially in the field of molecular microbiology, resulting in the development and application of powerful tools such as gene sequencing, fluorescence in situ hybridization (FISH), denaturing gradient gel electrophoresis (DGGE), terminal restriction fragment length polymorphism (tRFLP), and microautoradiography combined with 
fluorescence in situ hybridization (MAR-FISH) for the detection of hitherto uncultured taxa, their diversity and functions in the ocean (DeLong et al. 1989; Amann et al. 1990; Muyzer et al. 1993; Moeseneder et al. 1999; Lee et al. 1999; Ouverney and Fuhrman 1999).

To obtain accurate estimates of prokaryotic abundance, the preservation and processing of seawater samples is critical. Turley and Hughes (1992, 1994) reported cell losses of $7-75,65$, and $56 \%$ from glutaraldehyde- or formaldehyde-fixed seawater samples stored for $\sim 1.5$ 3.5 month at $17-22^{\circ} \mathrm{C}, 10^{\circ} \mathrm{C}$, and $6^{\circ} \mathrm{C}$, respectively. The cause of apparent cell loss is unclear, but it is thought that cell attachment to container surfaces and cell clumping may be involved. Turley and Hughes $(1992,1994)$ also found that cell loss could be avoided by fixing, staining, filtering, and mounting the samples within a few hours of collection and storing them in slide boxes at $-20^{\circ} \mathrm{C}$ until counted. Hyuan and Yang (2003) obtained highest prokaryotic cell counts when formaldehyde-fixed water samples were stored at $-20^{\circ} \mathrm{C}$ and thawed directly before slide preparation and microscopic evaluation. For the analyses of microbial communities by FISH and their activity by microautoradiography, it is also common to filter fixed samples and store them in petridishes at $-20^{\circ} \mathrm{C}$ until further processing (Fuchs et al. 2005; Elifantz et al. 2005; Teira et al. 2006).

However, keeping samples continuously at $-20^{\circ} \mathrm{C}$ during field work, at sea, and especially during transport back into the home laboratory from remote places is not always possible or practical and thus samples are sometimes thawed intermittently. In this study, we investigated the influence of storage temperature on fixed, filtered seawater samples for subsequent analyses of total prokaryotic abundance and community composition.

\section{Methods}

Sampling

Surface seawater was collected in an acid-rinsed polycarbonate bottle of the pier of Scripps Institution of Oceanography $\left(32^{\circ} 52^{\prime} \mathrm{N}, 117^{\circ} 15^{\prime} \mathrm{W}\right)$ on 22 February 2006. The sample was immediately transported to the adjacent laboratory and fixed with $0.2 \mu \mathrm{m}$ filtered formaldehyde (final concentration, $1.8 \%$, Sigma-Aldrich Inc., MO, USA, cat. no. F8775) for $1 \mathrm{~h}$ at $4^{\circ} \mathrm{C}$. Well-mixed $1 \mathrm{ml}$ subsamples were filtered onto black polycarbonate membranes $(0.2 \mu \mathrm{m}$ pore size, $25 \mathrm{~mm}$ diameter, Millipore, Billerica, MA, USA), rinsed with ultra-pure water and air-dried. Filters were placed in petridishes of $35 \mathrm{~mm}$ in diameter (three filter each, interspersed by the filter separators from the filter box). Twenty-seven filters were stored at $-20^{\circ} \mathrm{C}$ in the dark and an additional 27 filters were stored at room temperature $\left(\mathrm{RT}, 22-24^{\circ} \mathrm{C}\right)$ in the dark. A second sample of seawater was collected and fixed (same location and procedure) on 18 July 2006 for bacterial community analyses by FISH. Well-mixed $10 \mathrm{ml}$ sub-samples were filtered onto white polycarbonate membranes $(0.2 \mu \mathrm{m}$ pore size, $47 \mathrm{~mm}$ diameter, Millipore, Billerica, MA, USA), rinsed with ultra-pure water and air-dried. Two filters each were stored for 1 month in petridishes $(50 \mathrm{~mm}$ in diameter) at $-20^{\circ} \mathrm{C}$ and $\mathrm{RT}$ in the dark.

\section{Bacterial abundance}

Within less than $24 \mathrm{~h}$ (=day 1) triplicate filters from each treatment (i.e. $-20^{\circ} \mathrm{C}$ versus RT) were simultaneously stained and mounted on microscopic slides using a DAPIcontaining mounting medium (DAPI-Vectashield, Vecta Laboratories, Burlingame, CA, USA) and cells were counted via epifluorescence microscopy (Olympus BX51, $1,000 \times$ magnification, filter set U-MNU 2, Olympus, Tokyo, Japan). Because the filters from day 1 were not treated differently, mean cell counts included counts from all six filters. Mean cell counts were also estimated from triplicate filters of each treatment 8, 15, 22, 29, 43, 57, 78, and 99 days after collection.

\section{Bacterial community composition}

Bacterial community structure was analyzed by FISH as described previously (Pernthaler et al. 2001). Hybridizations were performed on triplicate filter sections which were stored for $28-30$ days at RT or $-20^{\circ} \mathrm{C}$. Fluorescently labeled (Cy3) oligonucleotide probes (Thermo Fisher Scientific, Ulm, Germany) were targeted to most organisms of the domain Bacteria (EUB338, EUB338-II, EUB338-III; Daims et al. 1999), Gammaproteobacteria (GAM42a and cGAM42a) and Bacteroidetes (CF319a; both Manz et al. 1992). The EUB338 antisense probe NON338 (Wallner et al. 1995) served as a negative control. Air-dried filter sections were counter-stained and mounted with DAPIVectashield. Cells were visualized by epifluorescence microscopy (see above, filter set U-MNG 2 for Cy3labeled cells) and phylogenetic groups were enumerated as percentages of all DAPI-stained cells in identical microscopic fields.

Statistical analysis

A 2-sided Student's $t$ test for paired samples was used to test for differences in cell counts between filtered samples 
stored at RT or $-20^{\circ} \mathrm{C}$. Endpoint comparisons to test for differences in cell counts between treatments on day 1 and day 99 were conducted with 2-sided Student's $t$ tests.

\section{Results and discussion}

Bacterial abundance in surface seawater collected from Scripps Pier in February was $2.34 \times 10^{6} \pm 1.74 \times$ $10^{5}$ cells ml ${ }^{-1}$ (day $1, n=6$, Fig. 1). Bacterial abundance was not significantly different between treatments (RT versus $-20^{\circ} \mathrm{C}$ ) at any time point ( $t$ test for paired samples, $P=0.24)$. Furthermore, cells counts from stored filters of the same water sample stained, mounted, and counted after 99 days were not significantly different from the filters counted at day 1 , whether they were stored at RT or $-20^{\circ} \mathrm{C}$ ( $t$ tests for endpoints, $P_{\mathrm{RT}}=0.73$ and $P_{-20^{\circ} \mathrm{C}}=0.77$ ). Bacterial abundance from seawater sampled, fixed and filtered in July was also not different between immediate counting and counting after 1 month of storage at RT or $-20^{\circ} \mathrm{C}$.

The detection rate of bacteria by FISH with Cy3-labeled oligonucleotide probes was $70 \pm 6$ and $72 \pm 1 \%$ of total DAPI counts when stored at RT or $-20^{\circ} \mathrm{C}$, respectively (Fig. 2). Bacteroidetes and gammaproteobacteria accounted for $29 \pm 3$ and $10 \pm 1 \%$ of total DAPI-counts, respectively, when filters were stored at RT and for $30 \pm 2$ and $10 \pm 1 \%$, respectively, when filters were stored at $-20^{\circ} \mathrm{C}$ (Fig. 2). No statistical test was necessary to show that there was no significant difference in relative abundance of the three tested phylotypes with respect to storage temperature. These data provide experimental evidence for the statement by Glöckner et al. (1996) that dried filters can be stored for several weeks at RT without apparent changes in FISH results. Furthermore, we detected no difference in perceived staining intensity and overall image quality between the two treatments upon microscopic visualization (Fig. 3) even though the less sensitive FISH technique with monolabeled fluorescent probes and not the highly sensitive TSA-FISH technique was applied. This indicated that cellular ribosomes were not significantly degraded within 1 month of storage at either RT or $-20^{\circ} \mathrm{C}$ and we see no reason why the more sensitive TSA-FISH method should work less well.

Often freshly prepared paraformaldehyde (PFA) is used as fixative for microbial cell counts and FISH analysis (Glöckner et al. 1996), but in our experience fresh formaldehyde gives equally good results for these purposes. Although both substances are potential carcinogens, the use of liquid formaldehyde eliminates the need for weighing and heating of the finely powdered PFA. However, the duration of fixation is crucial for optimal FISH results (Yang et al. 1999; Braissant and Wahli 1998) and fixed samples should be filtered and diligently rinsed within $24 \mathrm{~h}$ (Pernthaler et al. 2001). In conclusion, formaldehyde-fixed, filtered and air-dried seawater samples do not need to be kept frozen but can be stored at room temperature without cell loss (up to 99 days) or decrease in detection rates of phylotypes by FISH (up to 28-30 days). These time periods should be adequate for sample return to the laboratory even from remote sampling sites. We further note that the fixed and filtered but unstained samples can be stored at RT without a reduction in cell count. This simplifies the field processing of samples, and the unstained samples can be mounted with a DAPI-containing mounting medium and counted when it is logistically more practical to do so. This approach saves valuable time for sample processing in the field. Furthermore, it means that samples can be prepared with minimal resources, requiring only filters, a filter rig, and a hand-operated pump. Although we only analyzed samples from one coastal environment during two seasons, it is most likely that fixed and filtered samples from other habitats, e.g., freshwater or eutrophic, organically rich waters, can be stored at RT for later analyses of prokaryotic abundance and community composition as well. However, verification of this assumption is recommended for fundamentally different environments such as ultra-oligotrophic or deep-sea waters, in which microbial DNA- or ribosomal content might be extremely low.
Fig. 1 Prokaryotic cell counts from sub-samples of fixed and filtered coastal seawater stored at room temperature $(R T$, $22-24^{\circ} \mathrm{C}$ ) and $-20^{\circ} \mathrm{C}$ for up to 99 days and DAPI-stained prior to microscopic enumeration (mean \pm standard deviation; day $1, n=6$; all other, $n=3$ )

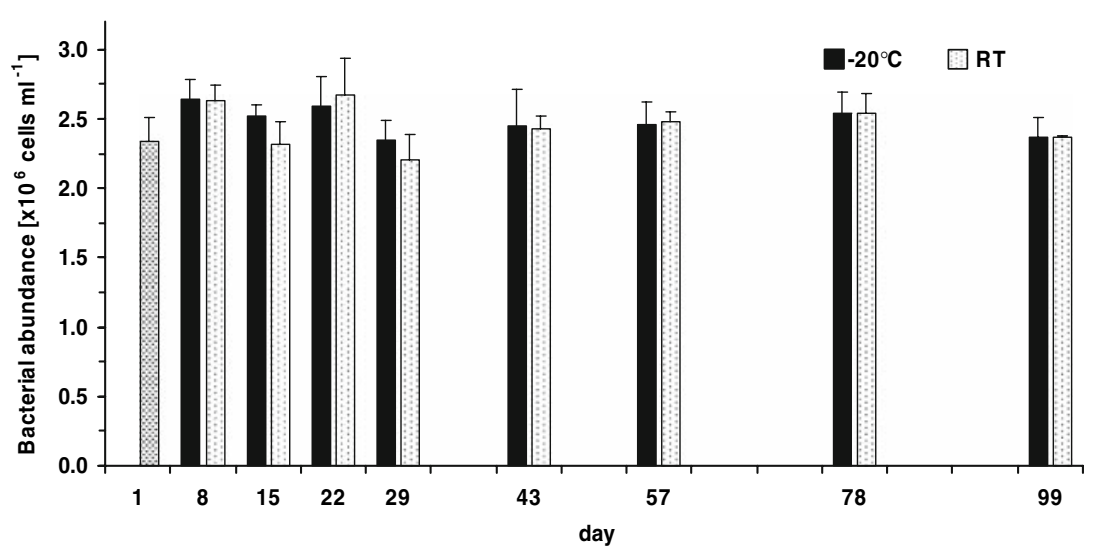




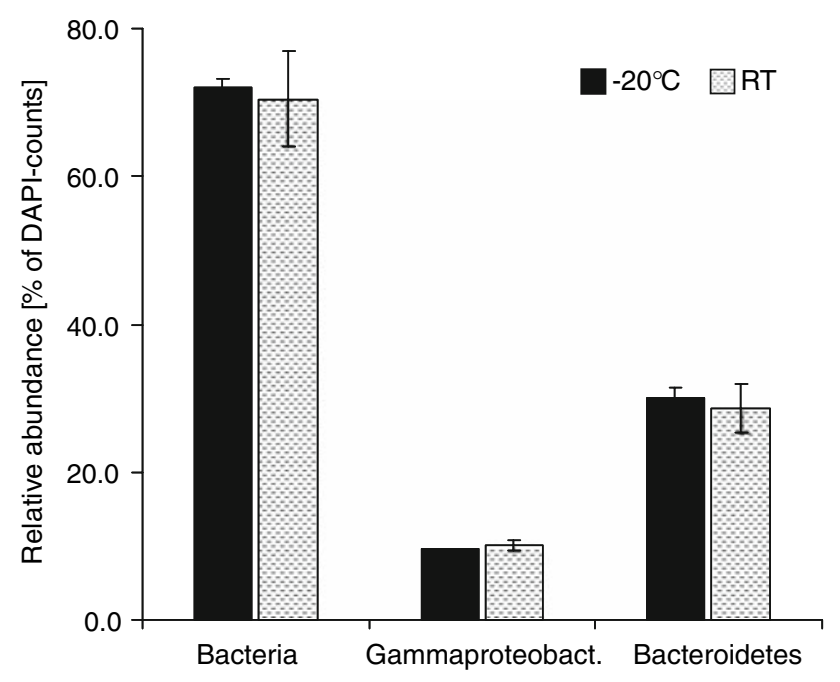

Fig. 2 Relative abundance of Bacteria (EUB338 I-III), Gammaproteobacteria (Gam42a), and Bacteroidetes (CF319a) of fixed and filtered coastal seawater stored at $R T$ and $-20^{\circ} \mathrm{C}$ for 1 month
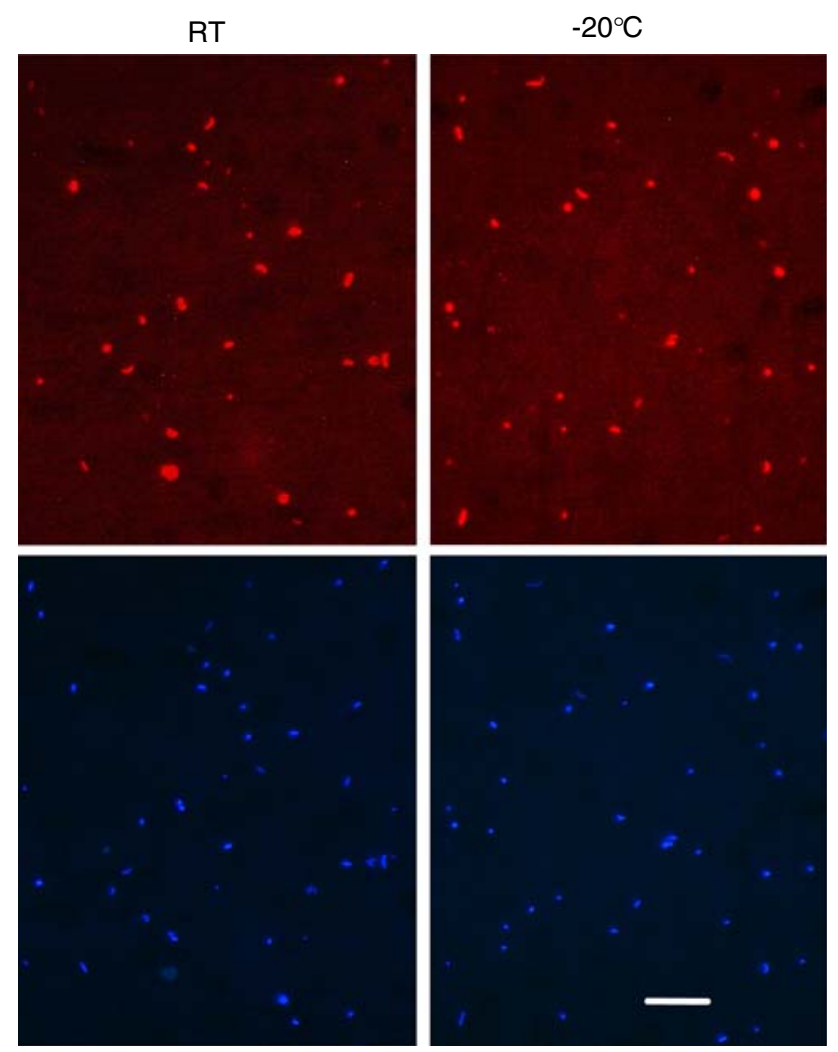

Fig. 3 Epifluorescence microscope images of fixed and filtered coastal seawater stored at room temperature $\left(R T\right.$; left panel) and $-20^{\circ} \mathrm{C}$ (right panel) for 1 month. Bacteria labeled with Cy3-EUB338 I-III (upper panel) and stained with DAPI (lower panel) in identical microscopic fields. Scale bar: $10 \mu \mathrm{m}$

Many types of investigations around the world that could benefit from the evaluation of microbial assemblages and dynamics currently are constrained because of a lack of facilities for advanced optical or molecular analyses. For instance, fish/shellfish pathogens can devastate aquaculture crops but farmers are rarely equipped to detect their occurrence or proliferation. They could easily filter, fix, and store water samples for subsequent analyses. Human pathogens in coastal and estuarine waters, e.g., Vibrio cholerae, could be monitored even in logistically challenging settings, by filtration and subsequent analysis in central laboratories. Given the breadth and potential value of resultant coverage, filters might be archived for future molecular studies, e.g., to detect emerging pathogens. Finally, studies of microbial ecology would benefit from setting up a network of sampling and analysis sites through collaborations for testing hypotheses on microbial diversity, biogeography and long-term changes in patterns of distribution of prokaryotes.

Acknowledgments We thank P. Nguyen and I. Huang for assistance in the laboratory and the US Department of Commerce, National Institute of Standards and Technology, Advanced Technology Program (70NANB1H3059) for financial support.

\section{References}

Amann RI, Binder BJ, Olsen RJ, Chisholm SW, Devereux R, Stahl DA (1990) Combination of 16 S ribosomal-RNA-targeted oligonucleotide probes with flow cytometry for analyzing mixed microbial populations. Appl Environ Microbiol 56(6):19191925

Braissant O, Wahli W (1998) A simplified in situ hybridization protocol using non-radioactively labeled probes to detect abundant and rare mRNAs on tissue sections. Biochemica 1:10-16

Daims H, Bruhl A, Amann R, Schleifer KH, Wagner M (1999) The domain-specific probe EUB 338 is insufficient for the detection of all Bacteria: development and evaluation of a more comprehensive probe set. Syst Appl Microbiol 22:434-444

Daley RJ, Hobbie JE (1975) Direct counts of aquatic bacteria by a modified epifluorescence technique. Limnol Oceanogr 20(5):875-882

Delong EF, Wickham GS, Pace NR (1989) Phylogenetic stainsribosomal RNA-based probes for the identification of single cells. Science 243(4896):1360-1363

Elifantz H, Malmstrom RR, Cottrell MT, Kirchman DL (2005) Assimilation of polysaccharides and glucose by major bacterial groups in the Delaware estuary. Appl Environ Microbiol 71(12):7799-7805

Fuchs BM, Woebken D, Zubkov MV, Burkill P, Amann R (2005) Molecular identification of picoplankton populations in contrasting waters of the Arabian Sea. Aquat Microb Ecol 39(2):145-157

Glöckner FO, Amann R, Alfreider A, Pernthaler J, Psenner R, Trebesius K, Schleifer KH (1996) An in situ hybridization protocol for detection and identification of planktonic bacteria. Syst Appl Microbiol 19:403-406

Hyun JO, Yang EJ (2003) Freezing seawater for long-term storage of bacterial cells for microscopic enumeration. J Microbiol 41(3):262-265

Hobbie JE, Daley RJ, Jasper S (1977) Use of nucleopore filters for counting bacteria by fluorescence microscopy. Appl Environ Microbiol 33(5):1225-1228 
Jones JG, Simon BM (1975) Investigation of errors in direct counts of aquatic bacteria by epifluorescence microscopy with reference to a new method for dyeing membrane filters. J Appl Bacteriol 39(3):317-329

Lee N, Nielsen PH, Andreasen KH, Juretschko S, Nielsen JL, Schleifer KH, Wagner M (1999) Combination of fluorescent in situ hybridization and microautoradiography—a new tool for structure-function analyses in microbial ecology. Appl Environ Microbiol 65(3):1289-1297

Manz W, Amann R, Ludwig W, Wagner M, Schleifer KH (1992) Phylogenetic oligodeoxynucleotide probes for the major subclasses of Proteobacteria: problems and solutions. Syst Appl Microbiol 15:593-600

Moeseneder MM, Arrieta JM, Muyzer G, Winter C, Herndl GL (1999) Optimization of terminal-restriction fragment length polymorphism analysis for complex marine bacterioplankton communities and comparison with denaturing gradient gel electrophoresis. Appl Environ Microbiol 65(8):3518-3525

Monger BC, Landry MR (1993) Flow cytometric analysis of marine bacteria with Hoechst 33342. Appl Environ Microbiol 59(3):905-911

Muyzer GE, De Waal EC, Uitterlinden AG (1993) Profiling of complex microbial-populations by denaturing gradient gelelectrophoresis analysis of polymerase chain reaction-amplified genes coding for 16S ribosomal-RNA. Appl Environ Microbiol 59(3):695-700

Ouverney CC, Fuhrman JA (1999) Combined microautoradiography16S rRNA probe technique for determination of radioisotope uptake by specific microbial cell types in situ. Appl Environ Microbiol 65(4):1746-1752

Pernthaler J, Glöckner FO, Schönhuber W, Amann R (2001) Fluorescence in situ hybridization (FISH) with RNA-targeted oligonucleotide probes. In: Paul JH (ed) Methods in microbiology, vol. 30. Academic, San Diego, pp 207-226

Porter KG, Feig YS (1980) The use of DAPI for identifying and counting aquatic microflora. Limnol Oceanogr 25(5):943-948

Teira EH, van Aken H, Veth C, Herndl GJ (2006) Archaeal uptake of enantiomeric amino acids in the meso- and bathypelagic waters of the North Atlantic. Limnol Oceanogr 51(1):60-69

Turley CM, Hughes DJ (1992) Effects of storage on direct estimates of bacterial numbers of preserved seawater samples. Deep Sea Res 39(3-4A):375-394

Turley CM, Hughes DJ (1994) The effect of storage temperature on the enumeration of epifluorescence-detectable bacterial cells in preserved seawater samples. J Mar Biol Assoc UK 74(1):259262

Wallner G, Erhart R, Amann R (1995) Flow cytometric analysis of activated sludge with rRNA-targeted probes. Appl Environ Microbiol 61:1859-1866

Yang H, Wanner IB, Roper SD, Chaudhari N (1999) An optimized method for in situ hybridization with signal amplification that allows the detection of rare mRNAs. J Histochem Cytochem 47(4):431-445

Zimmermann N, Meyer-Reil L (1974) A new method for fluorescent staining of bacterial populations on membrane filters. Kiel Meeresforsch 30:24-27 